\title{
The Transfer of Railway Technologies and Afro-Asian Labor Processes within the British Empire
}

\author{
Ian J. Kerr \\ History, University of Manitoba, Winnipeg, Canada \\ ikerr@mts.net
}

Abstract: The transfer of railway technology within the British Empire, and particularly to India provides the focus for this paper that explores-conceptually, historiographically and substantively-what was transferred and how that transfer took place. Drawing upon the large-scale technical system literature and labor history the paper highlights various kinds and levels of transfer agents working through, albeit in an often-contested fashion, Afro-Asian labor processes as central components within the transfer process when railway construction was involved. Railway construction is then counterpoised to railway operation where the transfer process exhibited greater British dictation and adherence to British practice.

Keywords: Colonialism/imperialism, infrastructure, railways, technology transfer, labor processes 


\section{Introduction}

This is a paper about the transfer of railway technology within the British Empire. Railway construction in colonial India, circa 1850 forward provides the substantive focus with the occasional mention of other British colonies in Asia and Africa. ${ }^{1}$ Similar to Dutch civil engineering in colonial Indonesia the examples in this paper show that the transfer of railway technologies to imperial dependencies cannot be understood as a simple process of diffusion outwards from the metropoles. To the contrary, globalization, localization, rejection and hybridization were involved. ${ }^{2}$ Railway technology had to be adapted to local conditions (environmental and social) within dialectical relationships shaped by Europeans and Asians and Africans albeit within contexts always influenced-and sometimes determined—by the power imbalances that characterize colonial situations. ${ }^{3}$

The paper proceeds largely via a literature review in order to highlight suggestions for ways forward in the study of technology transfer within the British Empire. ${ }^{4}$ The paper seeks, firstly and in the abstract, to establish what it was that was transferred; secondly and more substantively, to describe how the transfer of railway technology took place as lines came to be built in India and elsewhere; and thirdly by way of brief comparison, how line construction transfer and operating line transfer differed. Transfer agents of different kinds and levels of activity mediated through (smoothly or with difficulty) South Asian labor processes are highlighted as crucial to the transfer and operation of

\footnotetext{
${ }^{1}$ Both this paper and this thematic issue of HOST share the view that railways "played a decisive role in the shaping of the world.” The excellent historian of post-World War II Europe, Tony Judt, turned to railway history during his struggle with the debilitating, painful and always fatal ALS. Judt wrote: "I've learned much more concretely about the astonishing degree to which the railway-literally the railroad, trains, the whole economy it created-changed our world in ways that planes, cars, the Internet, even electricity maybe didn't quite match." The Nation, 17 May 2010. However, those changes were varied and multiple, took time, and exhibited content specific similarities and differences.

${ }^{2}$ Wim Ravesteijn, "Between globalization and localization: the case of Dutch civil engineering in Indonesia, 1800-1950," Comparative Technology Transfer and Society 5, no. 1 (2007): 32-65.

${ }^{3}$ On context read the cautionary viewpoint expressed by Stephen Gaukroger,

"Undercontextualization and Overcontextualization in the History of Science," Isis 107, no. 22 (2016): 340-42.

${ }^{4}$ Useful context for this paper is provided by Colin Divall, "From Waggonway to Bullet Train: Railway Engineering through the Millennium," Transactions of the Newcomen Society 76 (2006): 193-205.
} 
railway technologies to colonial India and elsewhere. Thus, this paper also supports Leo Lucassen's statement that there is "added value" when "labour relations and labour as an independent variable" are highlighted in the pursuit of global history. ${ }^{5}$

The last half of the $19^{\text {th }}$ century witnessed the construction and operation of revolutionary advances in transportation and communication. The volume of world trade increased tenfold between 1850 and the outbreak of World War I. ${ }^{6}$ O'Rourke argues that the "most impressive episode of international economic integration," the world has yet seen took place between 1870 and 1914. ${ }^{7}$ Western technologies based on the application of steam to locomotion - railways on land and steamships on oceans, lakes and riverssynergistically interwoven with the development of the electric telegraph, bigger and better harbors, and the Suez and Panama canals significantly decreased travel times, increased transportation volumes and reliability, and speeded up communication flows. Subsequently, the invention and widespread diffusion of new prime movers in the form of diesel engines (which displaced steam-powered ships in the 1930s) and gas turbines (hence jet aircraft in common use for international flights in the 1960s) continued the transportation revolution. ${ }^{8}$ It is a revolution that continues thanks to on-going innovation (incremental technological advance, e.g., larger and faster jet planes, giant ships and very fast trains) or invention (break-through technologies, e.g., especially where communication is involved the enormous consequences of the computer and the internet).

The above glosses a well-known story that intersects with another well-known story, namely the connections between that transportation revolution and western imperialisms

\footnotetext{
${ }^{5}$ Leo Lucassen, "Working together: new directions in global labour history," Journal of Global History 11 (2016): 66-87, on 68. H. Shelton Stromquist, "Railroad Workers and the Global Economy: Historical Patterns," in Global Labour History. A State of the Art, ed. Jan Lucassen, 623-47 (2nd ed.; Bern: Peter Lang, 2008) is a useful survey of the railway labor literature.

${ }^{6}$ Daniel R. Headrick, The Tentacles of Progress. Technology Transfer in the Age of Imperialism, 18501940 (paperback ed.; New York: Oxford University Press, 1988), 23.

7 Kevin H. O'Rourke, “Europe and the causes of globalization, 1700 to 2000," in Europe and Globalization, ed. Henri Kierzkowski, 64-86 (Basingstoke: Palgrave Macmillan, 2002), 65.

8 Vaclav Smil, "The two prime movers of globalization: history and impact of diesel engines and gas turbines," Journal of Global History 2 (2007): 373-94.
} 
in Africa and Asia. ${ }^{9}$ As a writer in an 1899 issue of the Engineering Magazine stated: "in the attacks which are being made by nearly all the nations of Europe for permanent territorial hold in Africa, engineering work is depended upon as a more certain and enduring form of attack than military power, and that the railway, the canal and harbor are the real weapons in the conquest of a continent." 10 The "tools of empire" literature places considerable significance on the roles steam locomotion played in facilitating, securing, maintaining and exploiting imperial possessions. ${ }^{11}$ Chris Bayly's seminal synthesis of global history captured a sharp-edged consequence of one type of steam locomotion, the railway, when he wrote: "The final rash of the wars of resistance by the world's native peoples had come between about 1850 and 1880, when Bengali Santals, Maori, Sioux, Ndebele, and Canadian Metis had battled a white invader now fortified with that most deadly of weapons, the railway." ${ }^{12}$

Bayly's reference to the Santals and to the railway as a particularly deadly tool of empire brings us directly to early railway construction in colonial India. A proximate cause of the Santal uprisings in eastern Bihar in 1855-56 was "the raping, bullying railway sahabs" involved in railway construction although the Santals also had other, longer-

\footnotetext{
9 This paper has neither the space nor the focus to discuss the theories and varieties of imperialism. However, in my view many investigations of the relationships between western imperialisms and the advances in transportation and communication should be informed by David Hardy's concept of "capitalist imperialism," "a contradictory fusion of 'the politics of state and empire' (imperialism as a distinctively political project on the part of actors whose power is based in command of a territory and a capacity to mobilize its human and natural resources towards political, economic, and military ends) and 'the molecular processes of capital accumulation in space and time' (imperialism as a diffuse political-economic process in space and time in which command over and use of capital takes primacy)." For an elaboration read David Hardy, The New Imperialism (New York: Oxford University Press, 2003), 26. Colin Divall identifies varieties of railway imperialism is his "Railway imperialisms, railway nationalisms" in Die Internationalitat der Eisenbahn 1850-1970, eds. Monika Burri, Kilian T. Elsasser and David Gugerli, 195-209 (Zurich: Chronos Verlag, 2003).

${ }_{10}$ Quoted in Casper Andersen, British Engineers and Africa, 1875-1914 (London: Pickering and Chatto, 2011), 23. This book supports many of the positions taken in this paper.

${ }^{11}$ Daniel R. Headrick, The Tools of Empire. technology and European imperialism in the nineteenth century (New York: Oxford University Press, 1981); Headrick, Tentacles of Progress. However, Headrick and others writing in the same vein must now be read in light of Clive Dewey Steamboats on the Indus. The Limits of Western Technology in South Asia (New Delhi: Oxford University Press, 2014) to caution us against facile assumptions that all Western technologies easily and/or successfully transferred to colonial possessions.

${ }^{12}$ C.A. Bayly, The Birth of the Modern World 1780-1914 (Oxford: Blackwell, 2004), 481.
} 
standing grievances. ${ }^{13}$ In Kubicek's words "technologies empowered the metropole but also, to some degree, strengthened the periphery. They may have cemented Imperial connections, but they could destabilize them as well." ${ }^{14}$

What made the railways and other transportation (and communication) technologies particularly important was their infrastructural role as large-scale socio-technical systems (LSTs) that enabled, facilitated, linked, and disrupted much else over extended areas. ${ }^{15}$ Railways made and remade interconnections across space and time. Dirk van Laak refers to railways as "the formative model of modern infrastructure" that inaugurated "the classical [emphasis in the original] era of networking and building technological landscapes ...."16

\section{What was transferred?}

The very idea of railways and how to build and operate them-that India and other British colonies in Asia and Africa could have integrated systems of railed transportation based on steam locomotion - was, in the first instance, that which was transferred, or,

${ }^{13}$ Ranajit Guha, Elementary Aspects of Peasant Insurgency in Colonial India (Delhi: Oxford University Press, 1983), 143.

${ }^{14}$ Robert Kubicek, "British expansion, empire, and technological change" in The Oxford History of the British Empire. Vol. III: The Nineteenth Century, ed. Andrew Porter, 247-69 (Oxford: Oxford University Press, 1999), 248.

15 Foundational texts include Thomas Hughes, Networks of Power. Electrification in Western Society 1880-1930 (Baltimore, The Johns Hopkins University Press, 1983); Hughes, "The Evolution of Large Technological Systems," in The Social Construction of Technological Systems. New Directions in the Sociology and History of Technology, eds. Wiebe E. Bijker, Thomas P. Hughes and Trevor J. Pinch, 51-82 (1987; Cambridge: The MIT Press, paperback ed., 1989); Bernward Joerges, "Large Technical Systems: Concepts and Issues," in The Development of Large Technical Systems, eds. Renate Mayntz and Thomas P. Hughes, 9-36 (Frankfurt am Main: Campus Verlag, 1988). Erik Van der Vleuten, "Infrastructures and Societal Change. A View from the Large Technical Systems Field," Technology Analysis \& Strategic Management 16, no. 3, (2004): 395-414 is an interesting contribution. One study in a colonial context explicitly situated in the large technical system literature is Wim Ravesteijn, "Dutch Engineering Overseas: The Creation of a Modern Irrigation System in Colonial Java,” Knowledge, Technology, \& Policy 14, no. 4 (2002): 126-44.

${ }^{16}$ Dirk van Laak, “Technological Infrastructure, Concepts and Consequences," Icon 10, no. 53 (2004): 53-64 on 58.

HoST - Journal of History of Science and Technology 12, pp. 31-74

DOI 10.2478/host-2018-0003 
more accurately in the case of the colonies, imposed by the colonial authorities. In the vocabulary of Ian Inkster colonial railways can be considered to be "technological projects" (hereafter TP). ${ }^{17}$ They were development projects (albeit development skewed to serve British interests) focused on a core technology, steam locomotion. Railway projects, in turn, were based upon a more encompassing and better integrated sociotechnological system(s) already present in Britain — an interrelated whole composed of, inter alia: physical artifacts (great and small, e.g., steam locomotives to nuts and bolts); production organizations; engineers, related professions and their professional societies; management structures; scientific/information networks; government bureaucracies; legislative institutions; law and regulations; and a good deal more. ${ }^{18}$ These socio-technical systems in turn were populated by a variety of actors ranging from high-status, powerful (politically and/or economically) individuals to the great numbers of skilled and unskilled workers whose collective labor physically built or operated the railways. Table one below illustrates the substantial numbers of workers required for railway-building projects.

\footnotetext{
${ }^{17}$ Ian Inkster, "Colonial and Neo-Colonial Transfers of Technology, Perspectives on India before 1914" in Technology and the Raj. Western Technology and Technical Transfers to India 1700-1947, eds. Roy MacLeod and Deepak Kumar, 25-50 (New Delhi: Sage Publications, 1995), 34-38. Inkster further argues that under colonial conditions a technological project (TP) was packaged in a closed-off way and deliberately related on an ongoing basis to the metropolitan technological system. Therefore, the developmental benefit of the project on technological advance within the receptor country was reduced. 18 British railways in their early main line phase, c. 1830-c. 1870 (or $c .1855$ depending on what characteristics are emphasized) were, of course, a study in complex, incremental change as a national network evolved, railway technology and operating practices became more routinized, and the rationalization and consolidation of the operating companies took place. See the stimulating contributions in Peter Cross-Rudkin, ed., Early Main Line Railways. Papers from the International Main Line Railways Conference (Clare: Six Martlets Publishing, 2016).
}

HoST - Journal of History of Science and Technology 12, pp. 31-74

DOI 10.2478/host-2018-0003 
Table 1 - Illustrative, Railway Construction Employment, 1850s-1920s

\begin{tabular}{l|lr}
\hline DATE & LOCATION & NUMBER \\
\hline 1857 & INDIA, MADRAS PRESIDENCY & 47,596 \\
$1860-61$ & WESTERN INDIA, GHAT INCLINES & 40,000 \\
1860 & INDIA, NORTHWEST PROVINCE (MODERN UP) & 43,841 \\
1881 & INDIA, OVERALL & 105,714 \\
$1888-90$ & INDIA, PUNJAB, SHER SHAH BRIDGE & 5000 \\
1890 & NATAL & 3000 \\
1891 & INDIA OVERALL & 190,008 \\
1899, & SIERRA LEONE & 1063 \\
1899 & LAGOS (SOUTHERN NIGERIA) & 10,426 \\
1899 & GOLD COAST (GHANA) & 2714 \\
1901 & KENYA (UGANDA RAILWAY) & 19,742 \\
1902 & GOLD COAST & 16,000 \\
1908 & NORTHERN NIGERIA & 5146 \\
1911 & NORTHERN NIGERIA & 13,000 \\
1922 & KENYA (UASIN GISHU RAILWAY) & 12,000 \\
\hline
\end{tabular}

Sources: India numbers come from the much larger data set available in Ian J. Kerr, "Constructing Railways in India--an estimate of the numbers employed, 1850-1880," Indian Economic and Social History Review XX, no. 3 (1983): 317-39 and Kerr, Building the Railways of the Raj 1850-1900 (Delhi: Oxford University Press, 1995); West African numbers can be found in Parliamentary Papers, 1904, Cd. 2325: West Africa, Papers Relating to the Construction of Railways in Sierra Leone, Lagos, and the Gold Coast (London: HMSO, 1904); and in Michael Mason, "Working on the Railway. Forced Labor in Northern Nigeria, 1907-1912", in African Labor History, eds. Peter C. W. Gutkind, Robin Cohen and Jean Copans, 56-79 (Beverly Hills: Sage Publications, 1978); the Uganda Railway figures come from M.F. Hill, Permanent Way. The Story of the Kenya and Uganda Railway, Being the Official History of the Development of the Transport System in Kenya and Uganda, (2 ${ }^{\text {nd }}$ ed.; Nairobi: East African Railways and Harbors, 1961) and Anthony Clayton and Donald C. Savage, Government and Labor in Kenya 1895-1963 (London: Frank Cass, 1974); Natal numbers appear in D.H. Heydenrych, "Indian Railway Labor in Natal, 187695: The Biggest Indian Work Force in the Colony," Historia (South Africa), 31 (1986): 11-20. Uasin Gishu numbers from John Mwaniki Mwaruvie, "Political Economy of Railway Extensions in Kenya: The Case of the Uasin Gishu Railway 1901-1930" (Ph.D. diss., West Virginia University, 2005), chapter VIII. 
Fundamentally, knowledge was transferred: knowledge that existed in a multiplicity of forms from the abstract to the specific; from tools and machines that represented objectified knowledge to the knowledge needed to use the tools and the machines; from what practice might be, to what was practiced. Managerial technologies"bodies of techniques, structures and principles"-were an important part of what was transferred and how it occurred. ${ }^{19}$ It was through these complex transfers that a particular technological project — a railway system, a telegraph system, a harbor, a mine-was undertaken and completed.

Marx would have labeled the physical results "the power of knowledge objectified" although he also would have recognized the socio-institutional framework that made the physical systems work. ${ }^{20}$ Technology is social and material. The relationship is continually recursive. But that, surely, is exactly that with which studies of technology transfers must deal, namely the transferal of reliable knowledge, validated techniques, skills, and devices to societies that had existing means and social relations of production. Because of British rule the TPs, the railways, as grand schemes were imposed on areas of Africa and Asia but with the caveat to which I will continually recur, the labor processes through which the lines were built and operated required adaptations between existing and relocated means of production.

Two points require emphasis. First, socio-technical systems are never unchanging entities. Innovation occurs. Component change generates systemic change. Growth and with it new contexts and new challenges must be overcome. ${ }^{21}$ Human actors within

\footnotetext{
${ }^{19}$ Richard Roberts, "French colonialism, imported technology, and the handicraft textile industry in the Western Sudan, 1898-1918," Journal of Economic History XLVII, no. 2 (1987): 461-72 on 461 and 471 .

${ }^{20}$ Karl Marx, Grundrisse, trans.with a forward by Martin Nicolaus, (London: Penguin, 1973), 706. "Nature builds no machines, no locomotives, railways, electric telegraphs, self-acting mules etc. These are products of human industry; natural material transformed into organs of the human will over nature, or of human participation in nature. They are organs of the human brain, created by the buman hand; the power of knowledge, objectified."

${ }^{21}$ In railway history highly consequential contraction has also taken place as in, for example, the line closures and restructuring in Britain after the Beeching reports of 1963 and 1965. Some largescale technical systems disappeared when their product/service was no longer required-the electric telegraph for example although one could argue that the telegraph morphed into the telephone. The latter and its landlines are now losing out to cell phones.
} 
a system accumulate improved knowledge and new techniques whose implementation affects system outcomes. It took, for example, a good many years of hard-learned experience before engineers learned how to build stable railway bridges across India's great rivers. But the basic point is straightforward: the configuration and components of a large scale socio-technical system as of a certain date is unlikely to be the same in some or many respects as it was twenty years earlier. As Hughes tells us: "Technological systems contain messy, complex, problem-solving components. They are both socially constructed and society shaping." ${ }^{22}$ In short, LSTs continually change.

Second, where railway transfer to India- or other colonies-was concerned we have the hard fact that the British knew how to build and operate railways. By 1850 when railway construction began on the Indian sub-continent over 6000 route miles were in operation in Britain. The technological template was well established, along with a substantial body of men knowledgeable in railway matters both with respect to construction and operation. Railways for India, therefore, was an eminently doable proposition once British government approval was forthcoming and financing available. Those hurdles took years to surmount but in 1849 two private, joint-stock companies, the East Indian Railway Company (EIR) and the Great Indian Peninsula Railway Company (GIPR) got the approvals and financing they needed including a Government of India-backed guarantee of a 5\% return to share holders on their capital investment.

\section{Constructing Railways in Colonial India: How?}

The transfer of transportation technologies was important in of itself and for what they subsequently effectuated. The broader story has been glossed above and is, in outline, a known history. What are less studied are the processes and agents whereby the infrastructural innovations in transportation were put into place and subsequently

${ }^{22}$ Hughes, "Evolution of Large Technological Systems," 51.

HoST - Journal of History of Science and Technology 12, pp. 31-74

DOI 10.2478/host-2018-0003 
operated. ${ }^{23}$ What was transferred as in the gloss above? By whom, to where precisely, and in what forms? How was the transferal effectuated, received, and mediated in the Afro-Asian world? How were Afro-Asian labor processes adopted, modified or replaced in order to build and operate railways? How were Afro-Asians co-opted or coerced into railway building and railway operation?24 These transfer processes, this paper suggests, had significant effects that existed separately from, but of course not unrelatedly to, the broader consequences for empire and globalization.

Put another way, the end results of technology transfer to the imperial periphery, e.g., the presence of an operating railway or a new harbor, had significant consequences for imperial connections and globalizing processes, as did the processes of technology transfer. Consider as one significant consequence of railway building the numerous Asians and Africans employed across many decades to build and to operate the railways - an engagement that had major consequences for the workers' lives, families and the societies in which they lived. The continuing employees of the operating railways (construction work was inherently discontinuous) often were the first and most numerous members of an industrial proletariat to emerge within any particular colony. The status of the initially much more numerous construction workers was more ambiguous but we do know that across Asia and Africa men, women and children in their cumulative millions were mobilized to build the railways, a mobilization that often required considerable spatial mobility on the part of those workers.

This paper does not address in any detail the multiple and complex ways in which the millions of construction workers were mobilized via mechanisms that ranged from those associated with free labor in the classical definition through to unfree labor in its most forced, direct, and physical manifestations. It is massive topic by itself, and one

\footnotetext{
${ }^{23}$ Works such as Clarence B. Davis and Kenneth E. Wilburn, Jr., eds., Railway Imperialism (New York: Greenwood Press, 1991) focused on political and diplomatic matters have less relevance when STS is the focus.

${ }^{24}$ Direct coercion was not unknown; less direct pressure was often present. Brief surveys of labor recruitment in colonial Africa can be found in Catherine B. Ash, "Forced Labor in Colonia Africa," History Compass 4, no. 3 (2006), 402-06 and Moses Ochonu, "African Colonial Economies: Land, Labor, and Livelihoods," History Compass 11, no. 2 (2013): 91-103.
} 
that exhibits a great deal of contextual variation. ${ }^{25}$ However, it is obvious that getting people to the construction sites was a necessary precondition for the use of their labor power.

A useful beginning is to return to Inkster's concept of technological projects. Railways for India was very much a project, or more correctly a number of projects (major lines) undertaken by the private, guaranteed railway companies under the overall direction of the GOI and its subsidiary jurisdictions with the Secretary of State for India (a cabinet minister) and his secretariat (the India Office) in London possessing final authority. ${ }^{26}$ Thus, the projected routes of the companies represented individual projects with their own staffs, suppliers, designated geographical areas of operation and so on. But, thanks to the overarching role of the GOI the parts-the individual projects - worked to a plan designed to construct a railway network across much of the Indian subcontinent regardless of the extent to which each company's body of lines remained an independent entity. The maps below display the growth of the railway network in colonial India: 1861-1871-1881; and a 1905 map that identifies the meter gauge and broad gauge lines.

${ }^{25}$ An entry point accompanied by a substantial bibliography is Tom Brass and Marcel van der Linden, eds., Free and Unfree Labour. The Debate Continues (Bern: Peter Lang, 1997).

${ }^{26}$ Technically, Parliament had the final say but that body rarely involved itself in Indian affairs.

HoST - Journal of History of Science and Technology 12, pp. 31-74 

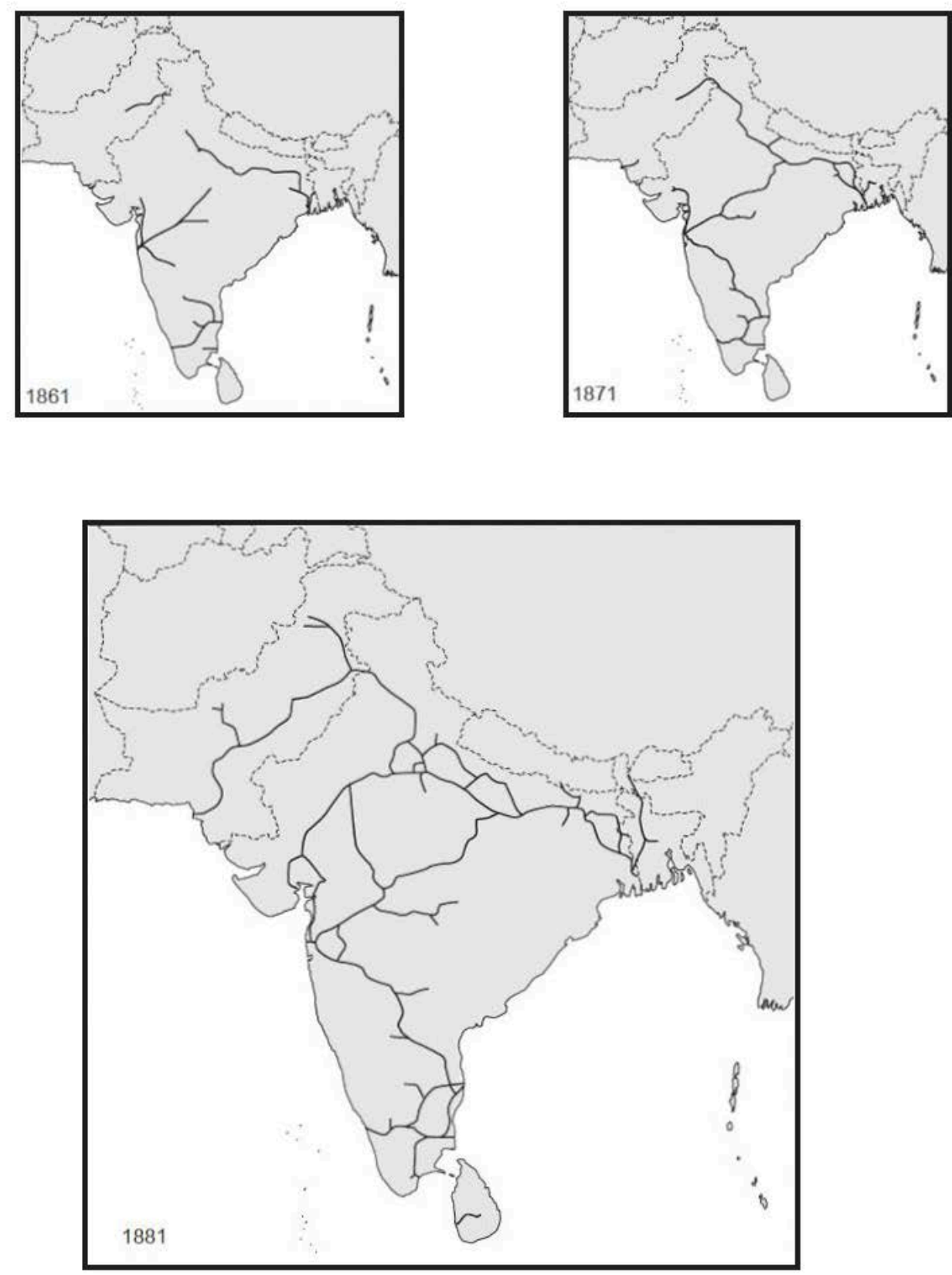

Map 1- Railways in India (all gauges), 1861, $1871 \& 1881$

Source: Doug Fast, cartography/Ian J. Kerr, data. See Ian J. Kerr, Engines of Change. The Railroads That Made India (Westport: Praeger, 2007), 21. 


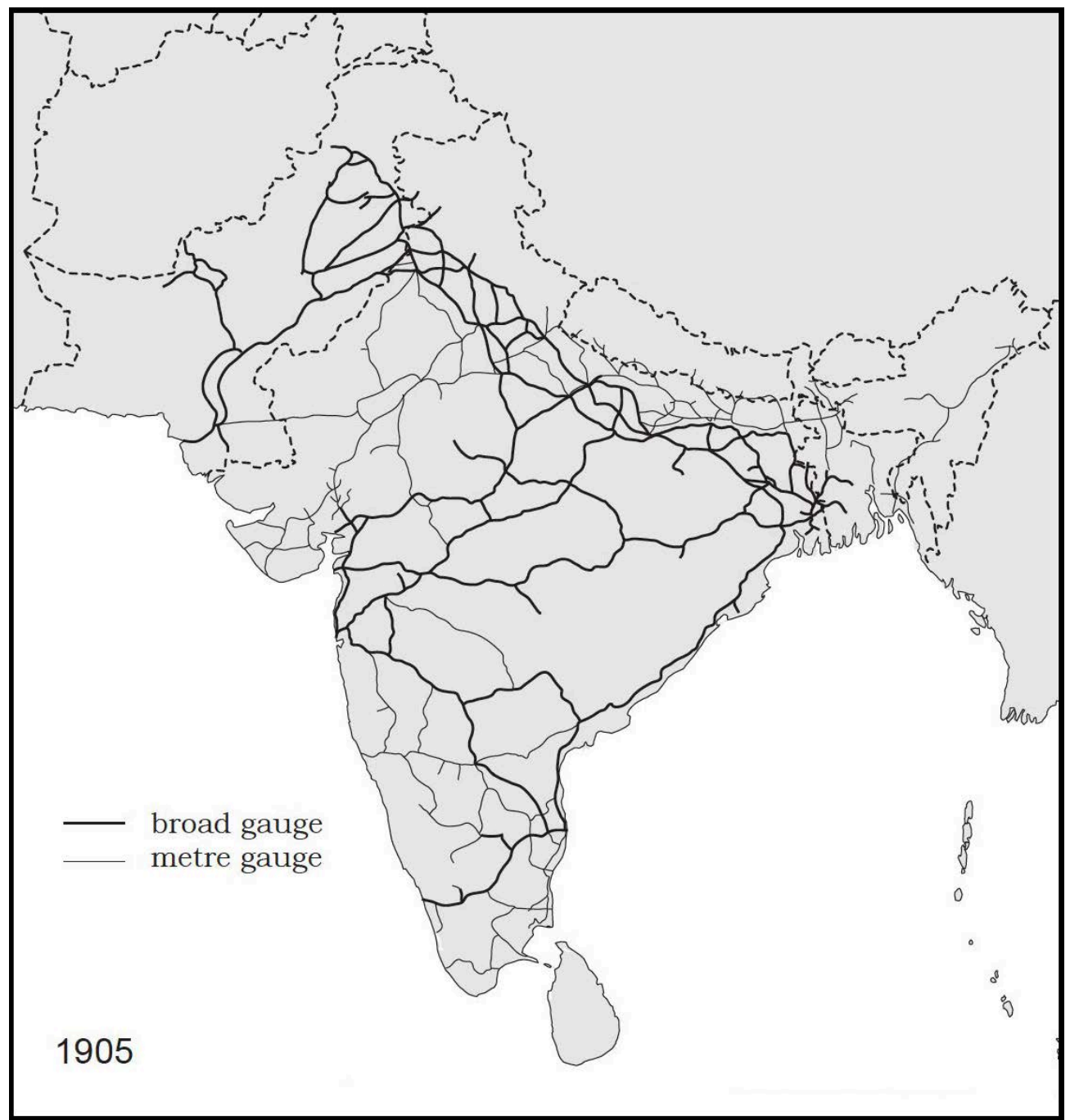

Map 2 - Railways in India, 1905

Source: Doug Fast, cartography/Ian J. Kerr, data. See Ian J. Kerr, Engines of Change. The Railroads That Made India (Westport: Praeger, 2007), 66.

This arrangement came to have an additional complexity when the GOI decided in 1869 to construct railways owned and managed by the State and to build many of these railways at the 3 ' 3 3/8" gauge (often labeled the meter gauge) rather than the hitherto standard 5' 6" gauge. The GOI made these decisions primarily for financial reasons. The existing system of private companies building expensive, broad gauge lines engineered to British standards had strained Government finances. Thus, another 
railway project was born under direct Government control.

An emphasis on these railway projects as a unit of analysis fits well with Philip Scranton's recent call for historians of labor and technology to focus on projects. Scranton writes: "In sum, exploring projects as business/technological history offers openings (...) toward appreciating the activities of traditional project-centered enterprises over the last two centuries." ${ }^{27}$ Scranton clearly sees railway building as a project and he observes:

Projects, other than permanent, high-profile corporate R\&D divisions, seemed peripheral or tangential to mainstream enterprise narratives. Equally, temporary organizations, even large-scale construction projects, represented short-term, ephemeral activities: the question of how railroads could be operated at a profit overshadowed issues of how they could be built in the first place. Again, this made sense in the Chandlerian era, though it's no longer tenable as historical practice. Such commitments help explain business history's long silence regarding building, publishing, military contracting, entertainment and fashion sectors, some of which at last are securing scholarly attention. ${ }^{28}$

This emphasis on projects opens the door to a greater emphasis on the project management dimensions of the work of railway construction engineers.

Because operating railways existed in Europe when the transfer to the periphery began the advocates of railway TP's knew what a railway system was and how it operated-all they had to ensure, or so they believed, was the relocation of the technological package, the idea and reality of railways as already well-established in the Europe. Relocation might require some adaptation to local conditions but basically a railway was a railway although, of course, subject to on-going, incremental change: However, and it was a crucial qualifier, how were the lines to be built? Where, precisely? When? How they were to be financed and, hence, who was to own and/or operate them (private capital or the State)? Who was to manage them or even, at the skilled levels, operate the machines? Where was the physical technology—engines, rails, bridge girders etc.—- to be bought?

${ }^{27}$ Philip Scranton, "Projects as a focus for historical analysis: surveying the landscape," History and Technology 30, no. 4 (2014): 354-73 on 361.

${ }^{28}$ A study that views railway construction through the prism of a project is Greet De Block, "Designing the Nation: The Belgian Railway Project, 1830-1837," Technology and Culture 52, no. 4 (2011): 703-32.

HoST - Journal of History of Science and Technology 12, pp. 31-74

DOI 10.2478/host-2018-0003 
Directly or indirectly this paper answers many of these questions - at least insofar as colonial India is concerned. Economic and political considerations dominated the central questions. And the answers significantly affected the developmental potential of the railways, their positive externalities, in their areas of geographical relocation. Thus, the colonial railways of India generated backward linkages but the multiplier effects of those linkages were, for an extended period, felt most strongly in Britain. ${ }^{29}$

In its most encompassing dimensions the overall project to develop a railway network in colonial India involved a large number of people in Britain, in India, and in transit (shipping). Many engineers, for example, of different ages, levels and kinds of experience, and seniority (e.g., consulting engineers in London, chief resident engineers in India, junior assistant engineers with limited experience at construction sites), contractors great and small, institutions (governmental and non-governmental), "interests and self-interests" both as groups and as individuals (financial, manufacturing, religious, military etc.), levels of government, and manual laborers—skilled and unskilled—in considerable number in Britain and India. Thus, with reference to the latter, manual workers in England manufactured most nuts and bolts used in India for decades by platelaying crews to attach one rail to another, as were the rails themselves. Railways for India involved a vast, integrated assembly of land (the right-of-way), labor, capital and production activities across the Anglo-Indian connection. Leland Jenks 1927 statement that British overseas railway ventures in the $19^{\text {th }}$ century are best conceptualized as "a migration of enterprise and labour and capital from one part to another of a commercial area conceived as an expanding economic whole" remains insightful. ${ }^{30}$

Transfer of railed steam locomotion to the colonies required transfer agents. These agents worked at culture-saturated interfaces where they used Asian and African labor and other local resources. Daniel Headrick provides a starting point when he

${ }^{29}$ W. J. Mcpherson, “Economic Development in India under the British Crown, 1858-1947," in Economic Development in the Long Run, ed. A. J. Youngson, 126-91 (London: George Allen \& Unwin, 1972), 145.

${ }^{30}$ Leland H. Jenks, The Migration of British Capital to 1875 (1927; London: Thomas Nelson, 1971), 178.

HoST - Journal of History of Science and Technology 12, pp. 31-74

DOI 10.2478/host-2018-0003 
distinguishes between different kinds of transfer agents-exporters, importers and migrants — and different categories of transfer: "the geographic relocation of technology by Western experts; its relocation by non-Western importers; its cultural diffusion by Western experts; and its diffusion by non-Western importers." ${ }^{31}$

However, Headrick distinguishes too sharply between the geographic relocation of technology involving equipment, methods and their accompanying foreign experts to operate them, and what he calls cultural diffusion when "knowledge, skills and attitudes related to a particular device or process" were transferred without the extensive and continuing involvement of foreign experts. ${ }^{32}$ David Arnold was more on the mark when he wrote: "Technological transfers are more likely to take the form of a 'dialogue' rather than a simple process of diffusion or imposition, and this was especially the case in India, which had a wide range of existing technologies and a physical and social environment far removed from that of Europe." ${ }^{33}$ Dictation was more prevalent in the case of railway technology than Arnold concedes but resistance, a contentious form of interaction (albeit not dialogue), was always present on the Indian side.

The processes of technological transfer were multi-faceted, interactive and dynamic. ${ }^{34}$ Foreign experts (and foreign capital and foreign entrepreneurs) certainly played a leading role in the transfer of railway technology but they were never the only players on the field. Indigenous railway workers in construction and operation were far from passive and never without their own technological histories: dimensions too little acknowledged by Headrick when he suggests the new technologies "shattered" existing relationships in the colonies and "laid the foundations for a new global civilization based on Western technology." 35 The integrative processes at the core of globalization rarely were unidirectional or sourced solely within the West.

\footnotetext{
${ }^{31}$ Headrick, Tentacles of Progress, 10

${ }^{32}$ Headrick, Tentacles of Progress, 9.

${ }_{33}$ David Arnold, The New Cambridge History of India, III, 5: Science, Technology and Medicine in Colonial India (Cambridge: Cambridge University Press, 2000), 92.

34 Bruce E. Seeley, "Historical Patterns in the Scholarship of Technology Transfer," Comparative Technology Transfer and Society, I, no. 1 (2003): 7-48 is a useful state of the field essay (as of 2003) but unfortunately for historians of the British Empire focused primarily on the United States after 1941.

${ }^{35}$ Headrick, Tools of Empire, 177.
} 
However, before we investigate further the roles Asians and Africans played in the development of the railways we need to provide illustrative information with respect to the British transfer agents. Only a few can be mentioned here but they highlight the need for prosopographical (collective biography) research, perhaps conducted by groups of collaborating scholars, to create databases that can provide a foundation for improved generalizations regarding the transfer agents. ${ }^{36}$

\section{Transfer Agents}

The transfer agents geographically relocated railway technology to the colonies. They provided, first, the knowledge appropriate to the development of railways as technological projects in the Afro-Asian world and, second, the managerial technology needed to build and operate railways, that is to put into practical, managed use a range of artifacts and labor inputs.

The agents existed at various levels of the transfer process: big picture visionaries who advocated or oversaw the transfer of the technological project(s) writ large; those who managed, again at different levels (from high-level engineers to work-gang overseers), the actual labor processes of railway construction and operation; the skilled workmen who physically participated in the work processes and who, as chargemen, taught their skills directly or indirectly to Asians or Africans.

We can easily imagine, and in many cases read, the textual and graphic material of the upper-level transfer agents, the documents that conveyed the knowledge needed to build a railway line: maps and blueprints, the specifications upon which contractors tendered their bids for substantial contracts, the detailed contracts between a major contractor and a railway company, or the specifications if the line was built departmentally, i.e., by a railway company's own engineers themselves acting as the prime contractor. What can only occasionally be glimpsed is the intense supervisory

\footnotetext{
${ }^{36}$ Lawrence Stone, "Prosopography," in Historical Studies Today, eds. Felix Gilbert and Stephen R. Graubard, 107-40 (New York: W.W. Norton, 1972).
} 
activity of a chief engineer as he applied his hard-earned technical and management skills to making sure the knowledge template was implemented properly. ${ }^{37}$ Those men constantly moved from the field to the office, from the written file to the personal, on-site instruction conveyed orally to a junior engineer. The chief engineers had a demanding job.

Transfer agents filled a variety of roles and worked at different levels and within different settings. They shaped processes and helped to determine outcomes. A few examples illustrate the variety of transfer agents involved in railway construction and operation. One group can be labeled the "big-picture visionaries." These men advocated railways for Asia and Africa, wrote and spoke about their plans, and in some cases became active promoters of particular railway lines. The latter moved beyond visionary statements to the active public and private work of raising political and financial support for their projects--a reminder if one is needed that financial considerations are always important in technological projects. Indeed, "the money trail" should become an integral part of the research agenda of STS argue three researchers. ${ }^{38}$ The big picture visionaries frequently invoked imperial needs and aspirations as part of their promotional campaigns; and they certainly made the connection between more specific metropolitan interest groups and the benefits to those groups colonial railways would provide-be it raw cotton from Western India to sustain the textile mills of the British Midlands or the cocoa bean of West Africa to nourish the chocolate industry.

A famous example of a big-picture visionary was Cecil Rhodes (1853-1902, a man for whom the Empire was both a magnificent concept and a mechanism for self-

\footnotetext{
37 A few engineers left revealing, detailed accounts of their activities. The Archives at the Centre for South Asian Studies at the University of Cambridge has the "Turnbull Papers" that include George Turnbull's (1809-1889) extensive diary. A posthumous, privately-published Autobiography of George Turnbull. With Added Extracts from His Diaries 1878-1889 (London, 1893) contain extensive excerpts from his India diaries. Turnbull was a prominent civil engineer who has an entry in P.S.M Cross-Rudkin et. al., eds., The Biographical Dictionary of Civil Engineers in Great Britain and Ireland [hereafter BDCE]. Vol. 2: 1830 - 1890 (London: Thomas Telford Publishing for The Institution of Civil Engineers, 2008). The British Library [hereafter BL), Asia, Pacific \& Africa Collections [hereafter APAC] has some private papers of engineers active in Indian railway construction and operation.

38 See Casper Andersen, Jakob Bek-Thomas and Peter C. Kjaergaard, "The Money Trail. A New Historiography for Networks, Patronage, and Scientific Careers,” Isis, 103 (2012): 310-15.
}

HoST - Journal of History of Science and Technology 12, pp. 31-74

DOI 10.2478/host-2018-0003 
enrichment) and his grandiose Cape to Cairo railway scheme: a project not completed although many of its lines were built. By 1910 Rhodes' British South Africa Company had built a substantial network in Rhodesia connected to the south with the South African Railways and to the north to the border of the Belgian Congo where a link was made with the Chemin de Fer du Haut-Katanga. ${ }^{39}$

A focal transfer agent in the early going in India was a British businessman named John Chapman (1801-1854). ${ }^{40}$ Chapman was not the colossus that was Cecil Rhodes but he worked tirelessly to make his dream, the GIPR come true. Without the relentless and visionary promotion of Chapman a railway system for Western India might have been delayed. A more personally successful individual, Sir Rowland Macdonald Stephenson (1808-1895, knighted 1856) played a similar role in the promotion and early operation of the coeval East Indian Railway that eventually extended from Calcutta to Delhi. ${ }^{41}$

Chapman commands our sympathy. To his dream-destroyed, premature death Chapman was burdened by his class background, religion and region of origin. Driven by the same characteristics he also believed that success would be his. Born into a Midland's artisan family the devoutly Baptist Chapman promoted the GIPR for nearly decade. He came to move on the edges of the moneyed circles of London from which the sharks and remoras of gentlemanly capitalism ousted him and consumed his dream. Chapman got $£ 2500$ as an adjudicated severance award and others came to control the GIPR. He died in September 1854 from cholera contracted during a visit to relatives in his natal town of Loughborough.

Nonetheless, Chapman was a central figure in the relocation of railway technology to western India, and a founder of one of the four railway companies that initially dominated the railway scene in India. As a transfer agent Chapman is a fascinating

\footnotetext{
39 "Notes on Railway Construction," Journal of the Royal African Society 12, no. 47 (1913): 290-95.

${ }^{40}$ A brief account of Chapman can be found in Ian J. Kerr, "John Chapman and the Promotion of the Great Indian Peninsula Railway, 1842-1850" in Across The Borders. Financing the World's Railways in the Nineteenth and Twentieth Centuries, eds. Ralf Roth and Gunter Dinhobl, 225-39 (Aldershot: Ashgate, 2008).

${ }^{41}$ Stephenson has an entry in $B D C E$, vol. 2.
} 
study. Much of his contribution took place in England: promoting in the first instance the idea of the GIPR, then getting investors interested and creating the necessary corporate structures, and then pursuing the economic, political and legal issues involved in getting permission to build and operate a railway in India. Many of the specifics of his technological project-for example the proposed routes of the initial lineswere determined by promotional needs. However, Chapman was also a man with technical learning and a good understanding of things mechanical and mathematical. He understood the power and the limitations of the steam technology of his time. He knew a crucial part of the relocation of railways to India had to be detailed surveys that established routes within the tractive powers of the locomotives of the day; he also understood the economics of railways, especially the trade-offs between gradients, average speeds, train loadings, fuel consumption and commercially promising routes. These issues took on particular prominence in the case of the GIPR because any line eastwards from Bombay had to go through the formidable Western Ghats. While Chapman was in India in 1845-1846 he personally engaged in reconnaissance surveys to identify a route through the Ghats. His survey notebooks survive in the British Library and testify to his abilities and knowledge of trigonometry. ${ }^{42}$ Surveys were a crucial step in line construction. Thus, as a transfer agent Chapman contributed to the processes of railway building in India at many different levels: promotional, managerial and technical.

The GIPR Directors fired Chapman in 1850, the same year in which railway construction began in India. In the East a line was begun northwards from Calcutta (that of the EIR) and, in the West, inland from Bombay. Of the two initial lines the GIPR faced by far the most difficult obstacle. The precipitous escarpment of the Western Ghats presented what some considered an insurmountable obstacle. Although the crest of the Ghats was only some 2000 feet above the narrow littoral of India's West Coast the ascent was abrupt and devoid of gentle passes that could facilitate the construction of a railway. Some argued railway inclines across the Ghats were not feasible. ${ }^{43}$ Nonetheless, after extended debate and the study of various routes, inclines at the Bhor and Thal

42 BL, APAC, Chapman Collection, Mss. Eur. E. 234, 24-79.

${ }^{43}$ Captain Edward Davidson, The Railways of India (London: E. \& F.N. Spon, 1868), 72-94.

HoST - Journal of History of Science and Technology 12, pp. 31-74

DOI 10.2478/host-2018-0003 
Ghats were approved. ${ }^{44}$

The latter decision involved the highest colonial authority in India, Governor-General Dalhousie. In the instance of the overall-project of railways for India Dalhousie acted both as a big picture visionary and as a crucial decision maker. The assured Lord Dalhousie (James Andrew Broun Ramsay, 1812-60, first Marquess of Dalhousie), Governor-General from 1848 to 1856, was one of the most able, hard working and assertive of the Governors-General. He was a committed technological modernizer. Indeed, in a self-congratulatory statement issued as he left office he claimed he had let loose in India the "great engines of social improvement, which the sagacity and science of recent times had previously given to Western nations-I mean Railways, uniform postage, and the Electric Telegraph.” ${ }^{45}$

Unusually among the aristocratic politicians/men of influence who became proconsuls in the British Indian Empire and elsewhere Dalhousie had a hard-earned, well-grounded understanding of railways. A stint (1843-46) as a member and then President of the Board of Trade (the latter in Prime Minister Peel's cabinet) had given him close familiarity with railway matters before he went to India. ${ }^{46} \mathrm{His}$ influential "Minute on Railways" issued in April 1853 provided the justifications and guidelines for the system of railways that were developed in South Asia in the third quarter of the $19^{\text {th }}$ century. ${ }^{47}$ The lengthy 1853 Minute became the foundational document that set many of the ground rules that guided the individual projects of the GIPR, the EIR

\footnotetext{
${ }^{44}$ James J. Berkley, Paper on the Thul Ghaut Railway Incline, read at the Bombay Mechanics' Institution in the Town Hall on Monday, December 10, 1860 (Bombay: Education Society's Press, 1861).

${ }^{45}$ Quoted in Gyan Prakash, Another Reason. Science and the Imagination of Modern India (Princeton: Princeton University Press, paperback ed., 1999), 160.

46 Therefore, Dalhousie is an important figure in British railway history and in the railway history of India. He merits an individual entry in the important reference work, Jack Simmons and Gordon Biddle, eds., The Oxford Companion to British Railway History, (Oxford: Oxford University Press, 1977). He is the main subject of a number of articles and books in Indian history. One book that gives special prominence to Dalhousie's role in the railway, electric telegraph and postal systems is M.N. Das, Studies in the Economic and Social Development of Modern India: 1848 - 56 (Calcutta: Firma K.L. Mukhopadhyay, 1959), chapts. 2 and 3 cover the railways.

${ }^{47}$ Bhubanes Misra, ed., Railway Construction in India. Select Documents. 3 vols (New Delhi: Northern Book Centre for the Indian Council of Historical Research, 1999) reprints in full many of the key documents for the period 1832-1900.
}

\section{HoST - Journal of History of Science and Technology 12, pp. 31-74}

DOI 10.2478/host-2018-0003 
etc., and melded those projects into an overarching project of railways for India. The initial trunk lines followed the routes delineated by Dalhousie, who in turn had been influenced by the writings of Rowland Macdonald Stephenson, promoter and first Agent in India of the EIR and others.

Dalhousie also contributed crucially to the decisions to depend on private British companies for India's first railways and to build the lines to a broad gauge, 5' 6". The latter decision had important consequences for both construction and operation. And later, 1869, when it was decided (and again colonial officials played central roles) to build State-owned and State-run railways in India to the meter gauge (3' $31 / 3$ "), a technical question involving a matter of inches, became a policy issue involving important political and economic considerations (e.g., the creation of two, semiindependent railways systems separated by break of gauge, trans-shipment points, and different rolling-stock).

Dalhousie, in sum, was a commanding representative of an important body of transfer agents found throughout the history of the British Empire: senior colonial officials well situated to influence the timing and content of technology transfer. ${ }^{48} \mathrm{~A}$ proconsul in Africa who had considerable influence on railway development in Nigeria and Kenya was Sir Percy Girouard (1867-1932): the Canadian engineer turned Royal Engineer turned colonial proconsul, first as High Commissioner in Northern Nigeria (19061909) and then as the Governor (1909-1912) of the East Africa Protectorate (Kenya). ${ }^{49}$ Like Dalhousie he had considerable knowledge about railway matters, and a keen interest in their development in the regions he administered.

Space permitting one could continue, project by project, along and down the layers of transfer agents to identify their particular contributions to specific colonial railway

\footnotetext{
48 The London-based Crown Agents, often in interaction with the major consulting engineers, played major roles in infrastructural construction projects in the British Empire in areas other than India. See David Sunderland, Managing the British Empire. The Crown Agents 1833-1914 (London; The Royal Historical Society, 2004). India did not fall within the jurisdiction of the Crown Agents.

49 John M. Mwaruvie, “Kenya’s 'Forgotten' Engineer and Colonial Proconsul: Sir Percy Girouard and Departmental Railway Construction In Africa, 1896-1912," Canadian Journal of History, XLI (2006): 1-22.
}

HoST - Journal of History of Science and Technology 12, pp. 31-74

DOI 10.2478/host-2018-0003 
projects. And thus, collectively and cumulatively, an improved understanding of similarities and differences within the processes of technology transfer would emerge. Major contractors, for example, could occupy vital roles. ${ }^{50}$ When the great Victorian contractor Thomas Brassey won the contract (in partnership with Wythes and Henfrey) in 1865 to build the 303 miles of railway from Delhi to Amritsar for the Sind, Punjab and Delhi Railway Company he did so on a complete turnkey basis including the provision of the rolling stock. ${ }^{51}$ In effect, the Brassey partnership handled the entire technological project and all of its associated components, physical and human. The Railway Company's engineers were reduced to the supervisory role of ensuring compliance with contractual specifications.

However, space does not permit so this discussion of transfer agents needs to conclude with the engineers, those agents that bulk largest in the historiography of technological transfer within the British and other Western Empires of the $19^{\text {th }}$ and early $20^{\text {th }}$ centuries. ${ }^{52}$ This was a body of agents that was itself variegated, hierarchical, and experiencing inter-generational change as those taught (some of the pioneers essentially were autodidacts) through apprenticeship and a wealth of experience (successes and failures) slowly gave way to more formally educated engineers as the training and work of the $19^{\text {th }}$ century engineer became professionalized..$^{53}$

The engineers had pivotal roles at multiple levels within transfer projects and, at the top level, within the broader, on-going British project to use technology to develop, "civilize", and exploit imperial possessions via "capitalist-imperialism." ${ }_{54}$ The apex

\footnotetext{
${ }^{50}$ Hugh Ferguson and Mike Chrimes, The Contractors (London: ICE Publishing, 2013).

${ }^{51}$ Kerr, Building the Railways of the Raj, 69.

52 Decades ago R.A. Buchanan provided a pioneering overview of what he labeled the "diaspora" of British engineering: "The Diaspora of British Engineering," Technology and Culture 27, no. 3 (1986): 501-24. We now have case studies of the colonial careers of a few individual engineers. An exemplar is Canay Ozden, "The Pontifex Minimus: William Willcocks and Engineering British Colonialism," Annals of Science, 71, no. 2 (2014): 183-205.

${ }_{53}^{3}$ R. A. Buchanan, The Engineers: A History of the Engineering Profession in Britain, 1750-1914 (London: Jessica Kingsley, 1989).

54 The connection between the technology transfers and the ideologies (including the "civilizing mission") of Western dominance is explored well in Michael Adas, Machines as the Measure of Men. Science, Technology, and Ideologies of Western Dominance (Ithaca: Cornell University Press, 1989).
} 
engineers were the elite consulting engineers located in what Andersen labels "Imperial Westminster," 55 "Affluent, vocal, influential and self-confident" they dominated "the market for engineering consulting projects in the British empire." ${ }_{56}$ Their imprimatur enabled projects to be funded; their project designs, overall supervision, planning and approvals enabled projects to proceed. Additionally, they usually recommended and/or approved the men, most certainly the senior men, who directed and engineered in situ railway and other projects in the Empire..$^{57}$

Thus, Robert Stephenson (1803-1859), arguably the most eminent of the consulting engineers in the 1840 s and 1850s, was the first consulting engineer of the GIPR. ${ }^{58}$ Stephenson most unusually and in demonstration of his wide knowledge and flexibility, was both an excellent civil engineer and a pioneer in what became a separate engineering discipline, namely mechanical engineering. In addition to his London-based consultancy, he was an active managing partner of a major locomotive manufacturing firm in Newcastle, Robert Stephenson \& Co. The latter firm submitted a bid to provide the first eight locomotives (type 2-4-0) for the GIPR but the order went to the much lower bid submitted by the Vulcan Foundry in Newton-le-Willows-a decision that reflected well on Stephenson's integrity. ${ }^{59}$

Stephenson nominated his long-term secretary and trusted associate, James John Berkley (1819-1862) to be the Chief Resident Engineer of the GIPR. Appointed 12 December 1849 Berkeley reached Bombay on 7 February 1850. He left India for the last time in April 1861 and died near London in August 1862, worn out and very ill

\footnotetext{
55 Andersen, British Engineers, 37.

56 Andersen, British Engineers, 6.

${ }^{57}$ My concern in this paper is with the British Empire, and within that primarily India. However, with contextual adjustment much of what I write can be applied to areas of "informal empire" or to the empires of other Western powers (and likely also to Japan in Korea and Manchuria).

${ }^{58}$ For a good account and assessment of Stephenson's wide-ranging and influential career read Michael R. Bailey, ed., Robert Stephenson - The Eminent Engineer (Aldershot: Ashgate, 2003).

${ }^{59}$ Hugh Hughes, Indian Locomotives. Part 1: Broad Gauge 1851-1940 (Kenton, Harrow: The Continental Railway Circle, 1990), 60 provides details of the initial bids to provide the first GIPR locomotives. This volume by Hughes and its three, subsequent volumes invaluably list and describe almost every locomotive put into service in India, broad gauge, meter gauge and narrow gauge, 1851-1990.
}

HoST - Journal of History of Science and Technology 12, pp. 31-74

DOI 10.2478/host-2018-0003 
from his labors in Western India. ${ }^{60}$ Within his accomplishments, notably supervising the building and operation of the initial lines of the GIPR, he personally conducted some of the detailed surveys that identified the route that enabled the permanent way to be built up the precipitous Bhor Ghat Incline without the use of a stationary engine. Berkley, arguably, had the most difficult project (because of the Ghat Inclines) among the three accomplished chief resident engineers who supervised the initial construction of railway lines in India: Berkley’s GIPR, George Turnbull (1809-1889) of the EIR, and Sir George Barclay Bruce (1821-1908) of the Madras Railway who in later career became an important consulting engineer. ${ }^{61}$

And, in a nuance to the recent emphasis on the feedback loops between colonies and metropoles with respect to transfers of scientific knowledge and practice, James Berkley was active in advancing understanding of science and technology within the dynamic context of a growing, commercially oriented Bombay. He became active in the Mechanics' Institution, became its Vice-President and then President, and he gave public lectures and wrote articles on scientific and technological topics. He was also a founding fellow and member of the governing senate of the University of Bombay. The James Berkley gold medal established in 1869 continues to be presented to the top civil engineering student at the University of Bombay. The feedback loops, this suggests, also included contact zones and diffusion processes within the areas to which Western experts geographically relocated a technology such as railways.

Let me conclude this discussion of engineers with one extended example of a remarkable but less known transfer agent from the later decades of the period covered in this article. The career of the civil engineer Francis Spring provides an extended entry point into the questions of technology transfer, transfer agents, human interfaces and AfroAsian labor processes. Spring was heavily involved in two-thirds of the steamshiprailway-harbor triumvirate upon which the global transportation revolution rested.

\footnotetext{
${ }^{60}$ Interestingly, Stephenson's successor as the GIPR's consulting engineer was Sir George Berkley (1821-1893; knighted KCMG, 1893), the younger brother of James Berkley. George also had been in Stephenson's employ, 1840-1849. Thus, for a few years the two brothers occupied the top engineer positions within the GIPR. Substantial entries with source notes for George and for John Berkley appear in $B D C E$, vol. 2.

${ }^{61}$ Turnbull and Bruce also appear in $B D C E$, vol. 2.
} 
Francis Joseph Edward Spring (1849-1933), later Sir Francis Spring after he was made a Knight Commander of the Indian Empire in 1911, was born in Ireland and educated at Trinity College, Dublin. ${ }^{62}$ Spring went to India in 1870 as a member of the Indian Engineering Service. Until 1873 he worked on canal irrigation in the Punjab-itself technology spurred in considerable measure by the developmental interests of the British. He then turned to railway work and made, maintained and administered railways in India until his retirement in 1904. Spring's career in India, however, did not end. Instead, from 1904 to 1919 he served as Chairman and Chief Engineer of the Madras Port Authority_-during the latter part of which he was also a member of the Madras Legislative Council.

As a railway engineer Spring did it all. He supervised the construction of some great railway bridges and became chief engineer for the East Coast Railway, director of construction for all the State Railways, a consulting engineer to Government, joint secretary of the Madras PWD and so on. By mid-career he successfully combined practical expertise, theoretical understanding and management skills. He learned from his Indian experiences and he contributed to the worldwide advance of hydraulic engineering in treatises like his River Training and Control published in 1903. ${ }^{63}$ The latter, a massive work still consulted in the $21^{\text {st }}$ century, exemplifies another globalizing theme, the growth of a corpus of technological and scientific knowledge shared worldwide based, in part, on experiences and experiments in the colonies and elsewhere in the non-Western world.

What the career of this gifted engineer shows is that effective agents of technological transfer were those who recognized the importance of the human dimension. Spring's ruling philosophy was "How shall I get it done best, most smartly, and cheapest, by direct dealings with the labourers." Spring's experiences demonstrated how the successful engineer had an interactive relationship with his workforce and with an

${ }^{62}$ A substantial entry for Spring appears in R.C. McWilliam and M. Chrimes, eds., The Biographical Dictionary of Civil Engineers in Great Britain and Ireland, Vol. 3: 1890-1920 (London: ICE Publishing, 2008).

${ }^{63}$ Francis Spring, River training and control, being a description of the theory and practice of the modern system entitled the guide bank system, used in India for the control and guidance of great alluvial rivers (Simla: Government Central Printing Office, 1903).

HoST - Journal of History of Science and Technology 12, pp. 31-74

DOI 10.2478/host-2018-0003 
evolving mix of tools, machines and techniques drawn from Britain and India.

Revealing are a number of measures Spring instituted when he was in charge of the construction of the great Sher Shah bridge (1888-1889) over the Chenab river (17 spans of 206 feet) in the Punjab and the Bezwada bridge (1890-1893) over the Kistna river (12 spans of 300 feet) in Eastern India. ${ }^{64}$ At the Kistna site Spring used bullockpowered dredges to excavate the bridge's foundation wells. Spring wrote that steam dredges were available on site but they were only marginally better "than the primitive bullock system as to justify its retention as a reserve to overawe the bullock-drivers, who were a troublesome and bad-tempered lot, always ready to strike." This is a striking example of the use of machines_-indeed, even more cleverly, the threat of the use of new machines - to control workers within a less-technically sophisticated but still effective work process. The colonial technological project, railways for India, was realized through socio-technical processes that blended the old and the new, imported techniques and machines alongside long-standing Indian techniques and work processes within overall labor processes shaped and controlled by foreign experts. ${ }^{65}$

Offering inducements to erecting gangs to compete with one another speeded up girder erection at Bezwada — a form of game playing designed to manufacture worker consent. ${ }^{66}$ Then, instantly the work was completed, the workers were paid off and put on trains to return to their native localities (great bridge construction in $19^{\text {th }}$ century India assembled workers from across the subcontinent). Thus, Spring's manipulation of his construction workers also demonstrates how the operating railways of India contributed to the mobility of labor-including labor needed to extend the railway system.

\footnotetext{
${ }^{64}$ Spring's activities at the two bridges, including direct quotation, is based on Spring's own, extensive report. See India, Director of Railway Construction, Technical Paper no. 71, F.J.E. Spring, "The Bridge of the North Western State Railway over the Chenab at Sher Shah, 17 spans of 206 feet, and the Bridge of the East Coast State Railway over the Kistna at Bezwada, 12 spans of 300 feet”. More details are available in Kerr, Building the Railways of the Raj, 152-56.

${ }^{65}$ A related, further level of abstraction, substance and the use of machine metaphors can be found in the stimulating Karel Davids, "On Machines, Self-Organization, and the Global Traveling of Knowledge, circa 1500-1900," Isis 106, no. 4 (2015): 866-74.

${ }^{66}$ Michael Burawoy, Manufacturing Consent. Changes in the Labor Process under Monopoly Capitalism (Chicago: University of Chicago Press, 1979).
} 
The enhanced mobility of labor was an important effect throughout Asia and Africa of the transportation revolution. Moreover, Indian workers in considerable numbers were used to build and operate railways in East Africa and Southeast Asia. 4000 Indian coolies, for example, were at work building the Uganda Railway in March 1897, 20,000 in March 1901, with 32,000 in total over the life of the project recruited from India, often as indentured laborers. ${ }^{67}$ Thus, in complicated processes of technology transfer, Indians who had learned railway-related skills in South Asia subsequently migrated temporarily or permanently to other regions where they were important participants (crucial in the Uganda case) in the labor processes of railway construction or operation.

Spring's activities reveal a good deal about how an effective transfer agent operated within the labor processes he commanded. Spring likely was more effective than many although there were others who had comparable abilities. However, among the engineers who went out to India in the last half of the $19^{\text {th }}$ century Spring was unusual insofar as he spent, except for furloughs, all his lengthy career-49 years — in India; a career extended by another unusual factor, his longevity. In an era when life spans were shorter, and when many engineers in the colonies died prematurely, Spring lived to retire, and to continue on to an age of 83 years. Those who survived often treated service in India as one posting in a career that might include service in more than one Asian, African or Latin American country but for whom the career goal was a good job in Britain. ${ }^{68}$ The pattern of movement in and out of India contributed to technological transfer across the globe and to the cross-fertilization of knowledge among engineers

\footnotetext{
${ }^{67}$ See Henry Gunston, "The Planning and Construction of the Uganda Railway," Transactions of the Newcomen Society 74, no. 1, (2004): 45-71 and Samuel G. Ruchman, "Colonial Construction: Labor Practices and Precedents Along the Uganda Railway, 1893-1903," International Journal of African Historical Studies 50, no. 2 (2017): 251-73.

${ }^{68}$ The engineers who proved to be the most effective transfer agents were those similar in personality to the more successful among a much later cohort of transfer agents, namely the technical experts that fanned out across the globe post-World War II as a result of the Cold war and decolonization. The latter exhibited "sensitivity to local circumstances; adaptability with regard to working conditions, local habits, and cultural practices; open-mindedness; humility; a sense of humor; patience; and diplomatic skill.” See Donna C. Mehos and Suzanne M. Moon, "The Uses of Portability: Circulating Experts in the Technopolitics of Cold War and Decolonization," in Entangled Geographies. Empire and Technopolitics in the Global Cold War, ed. Gabrielle Hecht, 43-74 (Cambridge: The MIT Press, 2011), 64. Technical expertise was important but not necessarily the central determinant of success as a transfer agent.
}

HoST - Journal of History of Science and Technology 12, pp. 31-74

DOI 10.2478/host-2018-0003 
but it limited the imprint of any particular engineer on India. Spring was an exception among the thousand plus who spent at least parts of their careers in South Asia. ${ }^{69}$

Our interest in Spring need not end with his direct accomplishments as a railway and harbor engineer. He was a man who wrote about technology, technical education, and the industrialization of India. As early as 1877 he published a 77-page pamphlet outlining a program of technical education in India in which he recognized the need to train Indians to become the skilled workmen the modern-sector of the economy needed..$^{70}$ In short, he saw the need to domesticate transferred technologies and to utilize those technologies within the processes of domestic production. In Headrick's terms Spring was interested in relocation and in diffusion.

\section{Construction Labor Processes}

Spring's recognition of the importance of his interactions with his workforces, and his clever manipulation of his workers and work processes to get the projects he supervised "done best" brings us to a central understanding where railways for colonial India was concerned. The railways could only be built—or at least built quickly and economically - through the labor power of very large numbers of Indians: cumulatively some ten million in the period 1850-1900. These millions were another large group to whom Thomas Metcalfe's statement, (primarily about indentured laborers), could apply: the "arms and backs of hundreds of thousands of Indian laborers alone enabled the empire, and by extension Britain itself, to prosper." ${ }^{71}$

\footnotetext{
${ }^{69}$ This summary statement is based on a very preliminary examination of my inchoate database of some 325 British railway engineers active in the later 19th and early 20th centuries. They represent a nonrandom sample because most individuals are present because they have an obituary in the Minutes of Proceedings of the Institution of Civil Engineers.

${ }^{70}$ Francis J. E. Spring, Technical Education for India (Calcutta: W. Newman \& Co., 1887). It was not a theme he abandoned. See his "Indian Industrial Development," The Imperial and Asiatic Quarterly Review, and Oriental Record, 3rd series, XXVII, no. 53 (1909): 225-51.

${ }^{71}$ Thomas Metcalf, Imperial Connections. India in the Indian Ocean Arena, 1860-1920 (Berkeley: University of California Press, 2007), 136-37.
} 
Africans and Asians came to railway work as men and women imbedded in existing forces and relations of production; they confronted, accepted and/or accommodated to the new tools and machines, ways of work, managerial strategies, and laws and legal structures derived from British statutes and practices. The general acts that governed railways and their employees in India were closely modeled on those of Britain. Laborspecific legislation in India in the $19^{\text {th }}$ century-only reluctantly abandoned some decades into the $20^{\text {th }}$ century - was rooted in the long-standing English law of master and servant, law that was abandoned in the metropole in the 1870 s but lived on in the colonies. ${ }^{72}$ Colonial impositions notwithstanding Africans and Asians shaped, in varying degrees, the labor processes used to construct and to operate the transferred technologies.

Nathan Rosenberg's statement captures an essential truth: "The notion of a production function as a "set of blue-prints" comes off very badly if it is taken to mean a body of techniques which is available independently of the human inputs who utilize it." ${ }^{73}$ Thus, like Rosenberg, this paper adopts a modified social constructionist approach to the issues of technology and technology transfer. Technology is neither fully determining nor fully determined hence one must reject the contingency of everything that the extreme practitioners of the social construction of technology embrace such that "all knowledge and all practice" becomes, in the words of one critic "only local, and no such thing as translocal, or spatiotemporally universal knowledge can exist outside purely local reification." ${ }^{74}$ Indeed, it would be inconsistent to acknowledge the existence of globalization (however difficult a concept to operationalize) while arguing for the contingency of everything.

\footnotetext{
${ }^{72}$ Ian J. Kerr, "Labour control and labour legislation in colonial India, a tale of two mid-nineteenth century acts," South Asia, XXVII, no. 1 (2004): 7-25. Comparative work on this topic is available in Masters, Servants and Magistrates in Britain and the Empire, 1562-1955, eds. Douglas Hay and Paul Craven (Chapel Hill: University of North Carolina Press, 2004).

${ }^{73}$ Nathan Rosenberg, "Economic Development and the Transfer of Technology. Some Historical Perspectives," Technology and Culture 11, no. 4 (1970): 550-75 on 555.

${ }^{74}$ Edward W. Constant II, "Reliable Knowledge and Unreliable Stuff. On the Practical Role of Rational Beliefs," Technology and Culture 40, no. 2 (1999): 324-57 on 326. Also see John M. Staudenmaier, "Rationality, Agency, Contingency. Recent Trends in the History of Technology," Reviews in American History 30 (2002): 168-81.
}

HoST - Journal of History of Science and Technology 12, pp. 31-74

DOI 10.2478/host-2018-0003 
The phrase "labor process" - and labor processes differ-is shorthand for the complex transformations of raw materials (which, in the case of railway construction, can be the landscape itself) by humans using tools and machines to make products for use and exchange. Labor process theory emphasizes "the social construction and conflictual character of work relations, science and technology." ${ }^{75}$ A labor process approach enables us to identify how workers used and altered the relocated technologies to which they were exposed, how these technologies intersected with existing relations of production, and how the Afro-Asian workers understood, accepted, rejected or subverted the new technologies to which the transfer agents exposed them. Philip Scranton epigrammatically captures the core meaning of labor process when he calls it "the point at which people and machine systems meet." ${ }^{76}$ Putting labor processes at the heart of STS, and particularly at the heart of detailed, substantive analyses of the on-the-ground implementation of the projects of technological transfer within the British Empire will go far to reveal the complex, interactive processes that brought those projects to fruition. ${ }^{77}$

One humble example from railway construction in India evocatively captures these adapted processes. British engineers wanted construction coolies to use wheelbarrows to move earth. The wheelbarrow was a simple piece of technology but it could move earth more efficiently than the headbaskets carried by women and children traditionally used in Indian earthwork. The hemispherical-shaped baskets—17 inches at the top, 10 at the bottom, and 6 inches deep-were in universal use in India. The illustration below (Figure 1) displays the headbasket and the powrah (short handled, broad-faced hoe similar to what in English is called a draw hoe or grub hoe): the two most used tools for earthworking in colonial India. English wheelbarrows were tried for railway construction near Bombay in November of 1850 but by March 1851 an engineer noted they had been abandoned in favor of the headbasket. He wrote that

\footnotetext{
${ }^{75}$ Paul Thompson, The Nature of Work. an introduction to debates on the labour process (Basingstoke: Macmillan, 1983), 11.

76 Philip Scranton, “ None-Too-Porous Boundaries: Labor History and the History of Technology," Technology and Culture 29, no. 4 (1988): 722-43 on 736.

77 For an expanded version of this plea see Martin Arboleda, "Revitalizing science and technology studies: A Marxian critique of more-than-human geographies," Environment and Planning D. Society and Space 35, no. 2 (2017): 360-78.
} 
after the initial experiments the wheelbarrow "was never adopted in future railway works at Bombay." ${ }^{78}$ Another engineer who worked (1867-75) on the construction of the Madras Railway recounts efforts to get earthwork coolies to use wheelbarrows only to find them carrying wheelbarrows on their heads "in the belief that it was only convenient modification of the principle." ${ }^{79}$ A similar story was told about earthworkers constructing the Suez Canal so the resistance of Indians to the wheelbarrow was not unique. ${ }^{80}$ However, in the Indian case it was long-lasting: headbaskets, or in some instances small donkeys with panniers of earth, continued to be a major form of earthmoving at construction sites until the late the $20^{\text {th }}$ century. ${ }^{81}$

\footnotetext{
${ }_{78}$ BL, APAC, Mss. Eur. D. 1184, West papers, West Memoirs, entries for 23 November 1850 and 3 March 1851.

${ }^{79}$ Quoted in Kerr, Building the Railways of the Raj, 175.

${ }^{80}$ Headrick, Tools of Empire, 153. Ferdinand de Lesseps shifted to more capital-intensive machinerygiant steam dredges - to get his canal finished. It is an example that reminds us that other construction methods could be used when conditions made them possible and/or desirable/necessary.

${ }^{81}$ Ian J. Kerr, Engines of Change. The Railroads That Made India (Westport, Conn.: Praeger, 2007), 61-2.
}

HoST - Journal of History of Science and Technology 12, pp. 31-74

DOI 10.2478/host-2018-0003 


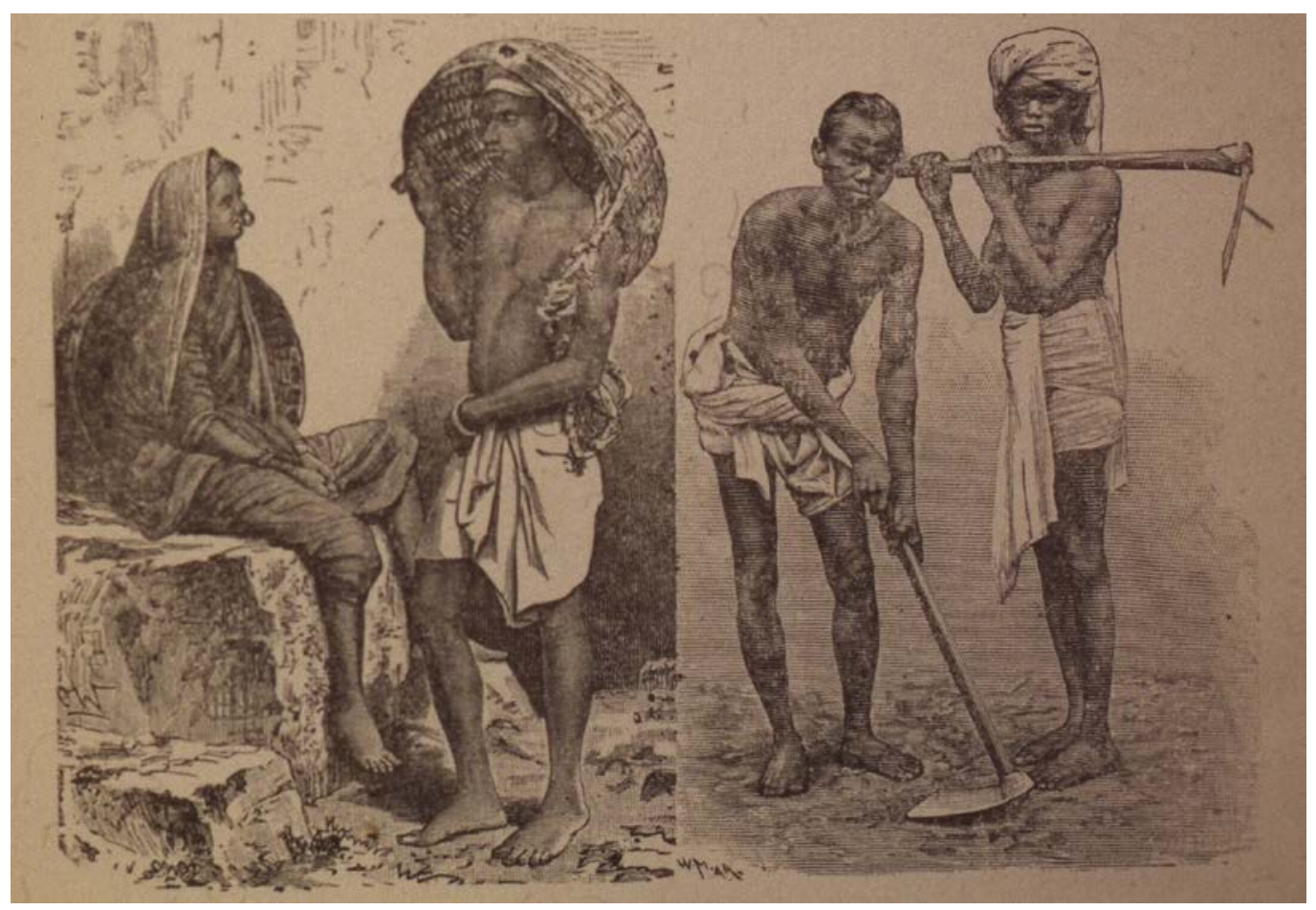

Figure 1 - Earthworkers, Headbaskets and Powrahs

Source: 19th century image in the author's collection of construction images.

The most successful transfer agents (engineers etc.) were those who best understood their managerial and pedagogical role—men who would have understood George Stephenson's lament when he said "I can engineer matter very well, but my great difficulty is in engineering men." ${ }^{82}$ What the transfer agents in various ways and at different levels of the transfer processes interactively managed/taught/co-opted/ modified-from the retired army sergeant turned overseer of gangs of earthwork coolies toiling in the burning sun, to a foreman in a railway workshop, to a GovernorGeneral of India in his substantial residence writing the minute that provided the basic template for India's railway system — was a labor process and/or knowledge of a labor process. The discrete, continually evolving, physical technologies of rail transport only became railways through a large-scale assembly of labor processes. The made world of the railways involved artifactual complexity and a sophisticated, managerial

${ }^{82}$ Robert Stephenson quoting his father George, The Engineer (25 April 1856): 233.

HoST - Journal of History of Science and Technology 12, pp. 31-74

DOI 10.2478/host-2018-0003 
technology. The operating railways were, in turn, the product of complex, construction labor processes carried out with relatively simple tools and machines, large amounts of capital, and an increasingly sophisticated, coordinated use of large numbers of human laborers.

Arguably therefore, in railway construction in colonial India and elsewhere the critical and novel accomplishment of the central transfer agents, the engineers, was not in the technical realm but rather in the coordinated management of the laborers. Certainly this was the view of Robert Wilfred Graham (1823-1917), a senior engineer of the GIPR who became its Chief Engineer in 1863 after the death of his boss, James John Berkley. Graham wrote that "the novelty" of the construction of the Bhor Ghat railway incline, a very demanding 16 mile ascent of the southeastern line of the GIPR through the precipitous Western Ghats some 34 miles east of Bombay, was not so much in the works themselves but rather in "the organization and adaptation of native labor to works of such magnitude" in "an inhospitable district". ${ }^{83}$ Indeed, Graham's statement applies to much of the railway building activity in $19^{\text {th }}$ century India. The key to the project(s) to transfer railways to India was the mobilization and utilization of the labor of large numbers of South Asians. Heidegger's musings on technology border on the metaphysical but his assertion that the "the essence of technology is by no means anything technological" resonates strongly within the transfer processes described in this paper. ${ }^{84}$

More difficult to document historically is the transfer of knowledge at the point of production where an Asian or African worker had to be convinced (or required) to work in a certain way, taught a new skill, or the use of a new machine. How did a junior engineer or a skilled chargeman cross the synapse whereby reliable knowledge known by a European became a work practice applied by a local worker? How did the Asian or African worker make it known that s/he (many earthworkers were women or children) would not fully adopt the European work practice or tool? And how or why did the

${ }^{83}$ Institution of Civil Engineers, London, Archives, Mss. 1161, "Description of the Bhore and Thul Ghat Inclines, Great Indian Peninsula Railway," 1866.

${ }^{84}$ Martin Heidegger, The Question Concerning Technology and Other Essays, trans. with an introduction by William Lovitt (1954; New York: Garland Publishing, 1977), 4.

HoST - Journal of History of Science and Technology 12, pp. 31-74

DOI 10.2478/host-2018-0003 
European sometimes acquiesce to the use of the indigenous tool or working practice?

Not surprisingly, something of the complexities of these transfer processes are better documented from the European perspective as in the example below. ${ }^{85}$

\begin{abstract}
To explain the process of regirdering to the men, who are mostly illiterate and talk half-a-dozen languages, a wooden model was made on a scale of $3 / 8$ inch to a foot. This included three piers, one old span, one new span, the service span, and the lifting-tackles with girders suspended from them. So before work began all the men engaged on it knew exactly what was to be done. Such a model is invaluable to engineers and sarangs alike in thinking out the leads of tackles, etc.
\end{abstract}

Nonetheless, we know Asians and African resisted or modified European-proposed transfers because the engineers mention the resistance they encountered, and the steps they, in turn, took to deal with that resistance. Thus, a very difficult piece of railway construction (1896-1904) in the hills of Assam saw the engineers use Indian tools and Indian work practices when possible. Even that which the engineers labeled Indian "prejudices" were tolerated in the interests of getting the job done. ${ }^{86}$ For the practical men involved in railway construction getting the job done provided the terrain of compromise, the dialectical dynamic, between themselves and the Africans and Asians whose labor power they sought to harness.

\title{
Operating Railways and Their Labor Processes: Some Differences
}

Spring's concern for the "Indianization" of India's technological advance leads to a few observations regarding the labor processes of colonial India's operating railways. The ruling assessment here must be Ian Derbyshire's judicious statement that "on balance, the consequences of adaptation to Indian conditions appeared significantly greater in construction than in either equipment or operations. Indeed, construction

\footnotetext{
${ }^{85}$ Harold Nugent Colam, "The regirdering of the railway bridge over the Krishna river, Madras and Southern Mahratta Railway, India: Fourteen spans of 150 feet," Minutes of the Proceedings of the Institution of Civil Engineers 227, (1929): 245-56 on 254.

${ }^{86}$ Kerr, Building the Railways of the Raj, 183
} 
was arguably of greater importance to the diffusion of technical skills than was railway operation itself". ${ }^{87}$ The relocated labor processes of railway operation coupled to the racial prejudices and biases the British exhibited in India (prejudices that themselves became determinants of aspects of the social dimensions of those labor processes) resulted in closer adherence to British-derived models of how railways should operate including detailed rulebooks, fines and other forms of discipline. And, of course, the physical artifacts of India's railways were very much British-made until late in the colonial period.

Those in authority resisted the extensive Indianization of the skilled and supervisory levels of the railway workforce. The influential 1921 "Report of the Committee appointed by the Secretary of State for India to enquire into the Administration and Working of Indian Railways" (command \#1512, session 1921), often known as the Acworth Committee after its chair and well-known railway expert, Sir William M. Acworth, described (p. 58) a permanent railway workforce of some 710,000 headed by some 7000 Europeans who, like a thin film of oil on top of water, rested upon but hardly mixed with the 700,000 Indians and Eurasians below. As late as 1939 over one-half of all positions on the railways designated as superior were occupied by Europeans while in the upper subordinate ranks - often the highly skilled positions in the workshops or the engine drivers-Europeans and Eurasians had a large presence. ${ }^{88}$ This resistance to the use of indigenous supervisory personnel and the failure to train skilled technicians appeared elsewhere within the British-controlled periphery. The British-controlled Suez Company (1882 onwards), like the Indian railway administrations, argued that because Egyptians lack the training of Europeans it was impossible to recruit them in

${ }^{87}$ Ian Derbyshire, "The Building of India's Railways: The Application of Western Technology in the Colonial Periphery 1850-1920" in Technology and the Raj. Western Technology and Technical Transfers to India, 1700 - 1947, eds. Roy MacLeod and Deepak Kumar, 176-215 (New Delhi: Sage Publications, 1995), 203.

88 Amba Prasad, "Indianization of Superior Railway Services," Modern Review 71 (1942): 161-64. Aparjith Ramnath provides a recent, scholarly analysis of the resistance to the Indianization of the senior ranks of the railways in chapter four of his The Birth of an Indian Profession. Engineers, Industry, and the State, 1900-47 (Delhi: Oxford University Press, 2017). Significantly, the chapter title includes "the Limits of Indianization on the Railways", a resistance less pronounced in other areas of engineering he examines.

HoST - Journal of History of Science and Technology 12, pp. 31-74

DOI 10.2478/host-2018-0003 
significant numbers "for skilled work and technical positions." ${ }_{89}$

Regardless, subordinate or not, railways in the colonies needed substantial, modernsector, industrial workforces drawn from the indigenous population in order to operate the railways. Table two below provides a few illustrative numbers. India, the overwhelming example and one for which good serial data exists, returned 160,563 Indian railway employees in 1881 plus 3,716 Europeans (almost entirely British) and 3625 Anglo-Indians (Eurasians) for a total of 167, 904; a number that became 354,902 by 1901 of whom 5,443 were Europeans and 7595 Anglo-Indians. The Anglo-Indians were disproportionately present (compared to their presence in India's total population) within the skilled and lower to mid supervisory ranks of the operating-line employees. ${ }^{90}$

The total figures for Kenya and Malaysia included a good many Indians while West Indians augmented the Nigerian numbers. The situation within the railways of the African white-settler colony of Rhodesia was even more complicated. ${ }^{91}$ The presence of these intermediary groups, usually within the better-paid, more-skilled and more senior ranks complicated the social dynamics of the labor processes of railway operation, as did the dominant presence of Europeans in the top jobs. ${ }^{92}$ It is an issue that requires extended, comparative investigation.

\footnotetext{
${ }^{89}$ Caroline Piquet, "The Suez Company's concession in Egypt, 1854-1956: modern infrastructure and local development," Enterprise and Society 5, no. 1 (2004): 107-27, on 123.

${ }^{90}$ For a more detailed analysis of the occupational niches of the Anglo-Indians see John Hurd and Ian J. Kerr, "Railway Management and Railway Employees in Colonial India," in Proceedings, Twelfth International Economic History Congress, ed. Clara Eugenia Nunez, 103-17 (Sevilla: Fundacion Fomento De La Historia Economica, 1998). A stimulating ethno-history of an Anglo-Indian railway community is Laura Bear, Lines of the Nation. Indian Railway Workers, Bureaucracy, and the Intimate Historical Self (New York: Columbia University Press, 2007).

${ }^{91}$ Jon Lunn, Capital and Labour on the Rhodesian Railway System 1888 - 1947 (Basingstoke: Macmillan, 1997).

${ }_{92}$ Relevant here is Ramnath, The Birth of an Indian Profession, chapt. four.
} 
Table 2 - Operating Railways, illustrative employment data

\begin{tabular}{|l|c|l|}
\hline Country & Total Employment & European Employment \\
\hline India, 1861 & 34,329 & 2181 \\
\hline India, 1881 & 167,904 & 3716 \\
\hline India, 1901 & 354,902 & 5433 \\
\hline Kenya, 1905 & 4533 & 53 \\
\hline India, 1931 & 754,750 & 4647 \\
\hline Malaysia, 1932 & 13,221 & 141 \\
\hline Nigeria, 1934 & 16,736 & 369 \\
\hline Sudan, 1941 & 18,551 & 269 \\
\hline
\end{tabular}

Sources: Extensive runs of a variety of serial data for India's railways are available in Morris David Morris and Clyde B. Dudley, "Selected Railway Statistics for the Indian Subcontinent (India, Pakistan and Bangladesh), 1853-1947-47," Artha Vijnana. Journal of the Gokhale Institute of Politics \& Economics, XVII, no. 3 (1975): 187-298. The annual employment figures appear in table 2. The entire Morris and Dudley compilation was reproduced on the CD ROM that accompanies Ian J. Kerr, ed., 27 Down. New Departures in Indian Railway Studies (Hyderabad: Orient Longman, 2007). The Kenya figures (the Uganda Railway) appear M. F. Hill, The Permanent Way. The Story of the Kenya and Uganda Railway (2nd ed.; Nairobi: East Africa Railways and Harbors, 1961), 290; Malaysian figures (Federated Malay States Railways) appear in Amarjit Kaur, "Working on the Railway: Indian Workers in Malaya, 1880-1957," in The Underside of Malaysian History. Pullers, Prostitutes, Plantation Workers . . . eds. Peter J. Rimmer and Lisa M. Allen (Singapore: Singapore University Press, 1990), 109, table 5.2; the numbers for Nigeria come from G. A. Oldfield, "The Native Railway Worker in Nigeria", Africa IX (1936): 379-402, on 379; and Sudan from Ahmad Alawad Sikainga, "City of Steel and Fire". A Social History of Atbara, Sudan's Railway Town, 1906-1984 (Portsmouth, NH: Heinemann, 2002), 48.

Lisa Lindsay's statement that "the government railway was the largest single employer of Nigerian wage labor throughout the colonial period" would find considerable applicability to many other British colonies where substantial railway development took place. ${ }^{33}$ These figures and a conclusion they generate deserve highlighting. Colonial railways became major employers of decently paid, reasonably secure, modern-sector industrial labor. Unlike their construction brethren operating line railway workers became a major part of the aristocracy of labor in colonies as diverse as India and Nigeria. Railway workers became a leading fraction of the emerging working class and, as such, had important influences on the trajectories of class formation and

${ }^{93}$ Lisa A. Lindsay, "No Need. . To Think of Home? Masculinity and Domestic Life on the Nigerian Railway," Journal of African History 39, no. 3 (1998): 439-66 on 440.

HoST - Journal of History of Science and Technology 12, pp. 31-74

DOI 10.2478/host-2018-0003 
class behavior in many colonies. Within the operating railways Asians and Africans were constrained by the labor processes within which they were enmeshed but as an emerging industrial proletariat they were a new social force in India and elsewhere.

Restricted though they were to subordinate railway jobs Indians (and the colonized elsewhere) acquired new skills thanks to their railway employment and the skilled Europeans under whom they worked. In the Lahore railway workshops in the 1870 s Indians could be seen "under a new aspect, busily employed in the care of huge machines which require constant vigilance and intelligent adjustment, working with an accuracy formerly undreamed of, and handling heavy weights with something approaching the muscular vigour of the Englishman." 94 The workforce included "a large number of Europeans, Eurasians and Parsis" among whom were twenty-five or so European foremen under whose "effective supervision" "native workmen are able to build railway carriages, and to do a great deal of useful metal and other work in repairing and fitting machinery."

Nor did the processes of skill transfer stop at the workshop door. J. Lockwood Kipling, Principal of the Mayo School of Industrial Arts in Lahore (and father of Rudyard) claimed that "an immense improvement" in carpentry and cabinet making in Lahore took place largely as the result of "the great numbers of men" trained in the railway workshops under European supervision. ${ }^{95}$ This suggests the presence of step-wise processes of skill transfer: Europeans to Indian workers in the shops and onwards into small enterprises and artisan activity in wood and metal influenced by workshop practice and sometimes manned by workers trained in the workshops. It is an earlier example of the 1916-18 Industrial Commission's statement that the railway workshops trained most engineering artisans, some of whom drifted in to private employment. ${ }^{96}$

However, the continued, substantial presence of Europeans and Eurasians in the managerial and skilled positions on the operating railways of India speaks to the

\footnotetext{
${ }^{94}$ Gazetteer of the Lahore District, $1883-4$ (Punjab Government, circa 1884), 182-83.

${ }_{95}$ Gazetteer of the Lahore District, 1883-4, 97.

${ }^{96}$ Indian Industrial Commission 1916-18. Report, 26.
} 
continuing, colonial-derived characteristics of the transfer of railway technology. ${ }^{97}$ Foreign experts - transfer agents — remained central to the transfer process and remained imbedded in the labor processes of the Indian railway industry almost to 1947. In 1937 another major railway enquiry committee argued that the "introduction of modern plant into workshops calls for men of experience in modern machine tool practice to train the operators." The Committee went on to argue that lack of experienced Indians meant the supervisors had to be of "European extraction." The Committee noted that in the few shops where European supervisors continued to be employed the use of modern machines "was noticeably better" but that the numbers of such supervisors had been reduced to imprudent levels. More were needed "to impart their skill and traditions to the Indian supervisors of the future." ${ }^{98}$

Why, even as deep into the colonial period as 1937, Indians had not been the recipients of the necessary supervisory skill and traditions is an important question; one that penetrates to central issues in the study of technology transfer and subsequent diffusion within the British Empire. Comparative study reveals a similar pattern of the continued domination of certain levels and kinds of railway positions by "Whites" in other colonies.

The evidence suggests that the relocated aspects of railway technology transfer to India were most pronounced and persistent in the realm of railway operation and less pronounced in railway construction. From the beginning the British required operating line employees, be they running staff or workshop employees, to possess skills, operate and wield the tools and machines, and to accept patterns of work organization and work discipline, as taught and managed to do so by British chargemen and foremen, similar to those used on British domestic railways. British engineers in the Assam hills in the 1890s used Indian tools and devices when possible "and where they did not affect the progress of construction, native customs of labor or even prejudices were not interfered with." ${ }^{99}$ Those in charge of the operating railways were less flexible.

\footnotetext{
${ }^{97}$ See Hurd and Kerr, "Railway Management and Railway Employees," 103-17.

98 Report of the Railway Enquiry Committee, 1937 (Delhi: Manager of Publication, 1937), 29.

99 Thomas Richard Nolan, "The Construction of the Ninth Division (Hills Section) of the Assam-Bengal Railway," Minutes of the Proceedings of the Institution of Civil Engineers, 178 (1909): 316-44 on 322.
} 
Arguably, a source of the difference lay in the labor processes needed to operate the capital-intensive artifacts of a network of railway lines as opposed to the more laborintensive processes involved in constructing those lines. I remain convinced that one revealing way of understanding that difference is through Marx's distinction between the formal and real subsumption of labor under capital. ${ }^{100}$ The former involved the subordination of labor to capital but except for improved organization, more continuity, and greater work intensity changes with respect to technology and work practices were limited-hence railway construction for much of Indian history. Real subsumption, that which Marx associated with what sometimes is labeled machinofacture, saw labor more thoroughly subordinated to capital (i.e., to the managerial and supervisory factotums) and to the machinery of production itself such that the technology of railed, steam transportation (e.g., driving a locomotive; signaling, rolling-stock repair work in a major workshop, etc.) became a controlling mechanism within the labor processes of railway operation. Unlike railway construction workers, the operating employees were subordinated to a leviathan that was technical and social. ${ }^{101}$

\section{Conclusion}

The British Empire in the early $20^{\text {th }}$ century spanned the globe. Such was its reach and extent-some fifty colonies located in virtually every continent, encompassing some 345 million peoples within 11.5 million square miles of territory-that it was a major driving force in the complex bundle of processes we label globalization. Transportation and communication networks undergirded and facilitated imperial interests of all sorts: political, military, and economic with each complex of interests

\footnotetext{
100 An elaborated view of the distinction and my application thereof can be found in Kerr, Building the Railways of the Raj, 7-9. Karl Marx's own formulation can be found in Capital, A Critique of Political Economy, vol. 1, introduced by Ernest Mandel, translated by Ben Fowkes (New York: Vintage Books, 1977), 944-45, 1019-49. Also useful is Paul Thompson, The Nature of Work (Houndsmill: Macmillan, 1983). The entry "labour process" in Tom Bottomore, ed., A Dictionary of Marxist Thought (Oxford: Blackwell, 1983) provides a concise explication of Marx's two forms of subsumption.

${ }^{101}$ For railways as leviathans read Frank McKenna, The Railway Workers 1840-1970 (London, 1980).
} 
usually intertwined with the others. Sir John Seeley caught the transformation well when he wrote: "Science has given to the political organism a new circulation, which is steam, and a new nervous system, which is electricity. These new conditions make it necessary to reconsider the whole colonial problem." ${ }^{102}$

This paper focused on a particular body of knowledge that was transferred to many parts of the world in the last half of the $19^{\text {th }}$ century in a seemingly endless procession of projects designed to bring railways (and much else) to this or that colonial possession. And, although it may seem counter intuitive to call something so concrete as railways "knowledge," the transfer of railway technology, as in all technologies, needs, in the first instance, to be seen as just that, the transfer of a body of knowledge.

Railways, however, are also very concrete, visible, physical things. They became visibly imbedded in landscapes as diverse as Deccan India and coastal Nigeria; they came to have an important, some would say a shaping, presence in many colonial cities; they became a palpable part of the everyday life of millions of Africans and Asians. Railways as one of the most important components of technology transfer to the colonial world presented themselves in two quite different but interrelated dimensions: (1) ways of knowing and doing and (2) physical things—-machines, tools, rails, signals etc., and etc.

Once the decision to transfer railway technology to India, Malaya, South Africa or Nigeria was made the question of how it happened needs to be addressed. This paper stressed two aspects of the transfer process. One was the role of transfer agents in relocating railway technology to India and elsewhere and remaining a major supervisory presence in the subsequent operation of the railways (and the on-going processes of technical transfer as operating railway technology evolved, and where path dependence became a significant force).

The second aspect was the need to recognize that all of the transfers required the use of the labor power of Africans and Asians whose existing socio-technical relationships had to be used, modified or replaced before railways could be constructed or operated.

102 Sir John Seeley, The Expansion of England. Two Courses of Lectures (London: Macmillan, 1883), 74.

HoST - Journal of History of Science and Technology 12, pp. 31-74

DOI 10.2478/host-2018-0003 
In railway construction a good deal of accommodation to Afro-Asian labor processes took place. In railway operation, on the other hand, Africans and Asians were required to conform much more to the labor processes characteristic of British domestic railway practice-British domestic practices themselves dictated in considerable measure by the artifacts and technical requirements of railway operation. However, in all cases Africans and Asian were not passive recipients of railway technologies. In one way or another there was a continuing "dialogue" — a dialectical relationship-between them and the Europeans who relocated the new technologies; and, at the level of structural interactions, between existing and new means and relationships of and in production.

Meanwhile, the foreign experts, the transfer agents, became important members of an emerging technical elite who moved from position to position across the globe-for the British engineers often but not always within the British Empire. ${ }^{103}$ These experts acquired experience in different localities and shared their knowledge: directly at work sites to colleagues and subordinates; and more indirectly via letters, lectures and professional journals. Knowledge, abstract as well as practical, about railways derived from colonial contexts and First World countries became shared, global knowledge-reliable knowledge as far as railwaymen were concerned. Colonial experience, adopted and sometimes transformed by the foreign experts, was universalized. Railway engineers in India studied Canadian and American practices; Spring's treatise on river training was read within that gung ho body of hydraulic manipulators, the U.S. Army Corps of Engineers. However, globalization did not mean the full-scale diffusion and indigenization of railway technologies. Africans and Asians participated in subordinate capacities in the processes of knowledge building and acquisition. Diffusion was limited. Relocation was far more common as the railway projects (TPs) remained closed-off and tied on an ongoing basis to the metropolitan technological system, to British manufacturers and to British experts.

${ }^{103}$ Men described as top mechanical engineering staff who were "birds of passage, using India as a stepping-stone to a larger career." See Fritz Lehmann. "Railway Workshops, Technology Transfer, and Skilled Labour Recruitment in Colonial India," Journal of Historical Research 20, no. 1 (1977): 49-61. 
However, globalization did not translate into equalization. In the social access to knowledge, as in much else, globalizing forces and technology transfers contributed to uneven development. ${ }^{104}$

104 Uneven (and combined) development has a long presence in Marxist thought. For a critical reconstruction read Marcel van der Linden, "The 'Law' of Uneven and Combined Development: Some Underdeveloped Thoughts," Historical Materialism 15 (2007): 145-65. A significance of this for STS in colonial contexts is the idea that "backwardness" provided the opportunity for the acquisition of technical advance in a colony without the time and development costs associated with intermediate stages. However, the result of such acquisitions was often, at best, a modified backwardness: witness India's colonial railways.

HoST - Journal of History of Science and Technology 12, pp. 31-74

DOI 10.2478/host-2018-0003 